\title{
Biochroma - A New and Patented Technology for Processing Radioactive Wastewater from Nuclear Medicine Therapy Facilities in Hospitals and Clinics
}

\section{José Canga Rodríguez}

José Canga Rodríguez, Key Account Manager - Pharmaceutical and Life Sciences Industry, EnviroChemie GmbH, In den Leppsteinswiesen 9, 64380 Rossdorf, Germany

\section{Introduction}

While undergoing nuclear medicine therapy using ${ }^{131}$ I radioisotope at a hospital, patients generate wastewater with a considerable amount of radioactivity. Thus, contamination can reach levels of as much as $90 \%$ of the radioactive dose administered to the patient, depending on the type of therapy the patient underwent $[1,2]$. Given its radioactive half life of 8.02070 days, there is a significant risk of ${ }^{131}$ I radioisotope accumulation after its discharge into the sewer network (through sanitary wastewater) and into the environment. Therefore, it is advisable to collect this effluent in a separate system for its treatment prior to final discharge to the municipal sewer [3-8].

In spite of the clear scientific evidence of the severe contamination of this specific type of wastewater, a harmonised legal framework has still not been devised for all member states of the European Union. A survey conducted by the Radiological Protection Institute of Ireland clearly spotlights the discrepancies existing among concepts for managing radioactively contaminated effluents. The survey examined thirteen countries, six of which stipulate the installation of wastewater treatment systems (Table 1), three of which permit the wastewater to be discharged directly following dilution (Table 2) and four of which permit both options (Table 3), depending on the specific conditions of the respective sanitary system [9].

Delay and decay (natural decomposition of the isotope) is the most commonly used technical method of abating ${ }^{131} \mathrm{I}$, but it is frequently criticised as being complex and very expensive [10-13]. While searching for alternatives to this old-fashioned technology, EnviroDTS (a subsidiary of the EnviroChemie group of companies) developed an alternative method called BioChroma, which is patent protected. This paper describes the technology and presents, as an example, a system that was installed and commissioned in the middle of 2008 in a nuclear medicine therapy facility with 12 beds in Stuttgart (Germany).

\section{Description of the BioChroma process}

BioChroma is a new and patented biological treatment system with a final adsorption phase. This technology is based on a thorough optimisation of wastewater treatment concepts, which are based on the physical principle of chromatography and were developed and built in the late 70's for hospitals in Wuppertal and Würzburg (Germany).

The performance of these systems in the biological treatment stage was inadequate because the sanitary sewage was too highly contaminated with nutrients. As a result, the adsorption phase using activated carbon did not perform as well as had been expected. All of which resulted in expensive operating costs since the activated carbon had to be replaced frequently and increased manpower resources were needed to operate the system. Delay and decay technology (Picture 1) was developed as a result of this failed attempt and it became the standard approach to handle this kind of wastewater.

This type of treatment plants is subject in Germany to the stringent provisions of the "Radiation Protection Ordinance"
(Strahlenschutzverordnung) [14], which also governs the operation of radiological treatment wards. The Ordinance is joined by the DIN 6844-1 [10] and DIN 6844-2 [11] standards, which define the binding appliances and equipment that must be used by nuclear medicine diagnostic and therapy facilities, including the systems for processing radioactive wastewater. Taken altogether, these standards and regulations make the construction of delay and decay systems very complex and require enormous investments in equipment and space.

BioChroma was developed as an alternative to these complicated and expensive systems, whereby the fundamental elements of the chromatography-based technology were used and optimised in a way that mistakes of the past could be avoided.

The BioChroma system (Figure 1) collects the wastewater generated at the radiological therapy ward in buffer tanks fed by special pumps, which are fitted with a device that shredders the solid matter and thus homogenises the effluent. Equipped with an aeration system, these holding tanks act as a precursor to the biological treatment stage, as well as they help to avoid anaerobic processes and their associated problems of unpleasant odours.

Before reaching the biological treatment plant, the wastewater is pre-clarified at a sedimentation stage, where larger particles, which might hinder the performance of the activated sludge in the biological reactor, are separated.

The process phase that then follows represents the major improvement that makes the BioChroma system so special: an optimised biological treatment plant that is installed upstream of the adsorption filtration phase. This biological reactor is comparable to a small plant for processing municipal wastewater. It is equipped with a secondary clarification stage and a filter to separate any suspended solids. Thus, final organic contamination is reduced to a minimum and the downstream adsorption filter system can be protected.

The already mentioned final adsorption filter line consists of activated carbon filters and selective ion exchangers for eliminating the dissolved radioactive components in the wastewater before it

Corresponding author: José Canga Rodríguez, Key Account Manager Pharmaceutical and Life Sciences Industry, EnviroChemie $\mathrm{GmbH}$, In den Leppsteinswiesen 9, 64380 Rossdorf, Germany, E-mail: jose.canga-rodriguez@ envirochemie.com

Received August 19, 2011; Accepted November 16, 2011; Published Novembe 19, 2011

Citation: Rodríguez JC (2011) Biochroma - A New and Patented Technology for Processing Radioactive Wastewater from Nuclear Medicine Therapy Facilities in Hospitals and Clinics. J Nucl Med Radiat Ther 2:117. doi:10.4172/21559619.1000117

Copyright: (c) 2011 Rodríguez JC. This is an open-access article distributed under the terms of the Creative Commons Attribution License, which permits unrestricted use, distribution, and reproduction in any medium, provided the original author and source are credited. 
Citation: Rodríguez JC (2011) Biochroma - A New and Patented Technology for Processing Radioactive Wastewater from Nuclear Medicine Therapy Facilities in Hospitals and Clinics. J Nucl Med Radiat Ther 2:117. doi:10.4172/2155-9619.1000117

Page 2 of 6

\begin{tabular}{|c|c|c|c|}
\hline \multirow{2}{*}{ Country } & \multicolumn{2}{|c|}{ Management approach } & \multirow{2}{*}{ Notes } \\
\hline & Direct discharge & Wastewater treatment & \\
\hline France & & $\checkmark$ & $\begin{array}{l}\text { Effluents eliminated by patients in protected rooms (iodine dose }>740 \mathrm{MBq} \text { ) are normally collected } \\
\text { via bi-sectional toilets. Effluents from ordinary sanitary installations in the nuclear medicine unit } \\
\text { are usually linked to a septic tank. Due to the length of time the material stays in the septic tank. } \\
\text { The volume activity of the radionuclides in the collector is thus greatly reduced before release into } \\
\text { sewage network. }\end{array}$ \\
\hline Germany & & $\checkmark$ & $\begin{array}{l}\text { All facilities are required to have holding tanks installed and discharges from facilities must remain } \\
\text { below a limit of } 5 \mathrm{~Bq} / \mathrm{l} \text { at the point of discharge into the public wastewater network. }\end{array}$ \\
\hline Northern Ireland & & $\checkmark$ & $\begin{array}{l}\text { Decay storage is used, although it is not a regulatory requirement. Activity concentration limit is set } \\
\text { at } 80 \mathrm{kBq} / \mathrm{l} \text { prior to discharge to sewer. }\end{array}$ \\
\hline Lithuania & & $\checkmark$ & $\begin{array}{l}\text { Wastewater is retained in holding tanks for between } 30 \text { and } 60 \text { days prior to discharge to sewer. } \\
\text { Two tanks are used, one being filled as the other is left to decay prior to discharge. }\end{array}$ \\
\hline Luxemburg & & $\checkmark$ & $\begin{array}{l}\text { All new treatment facilities are required to install holding tanks, with patient excreta being held for } \\
\text { a minimum of } 210 \text { days prior to discharge. Activity concentrations of }{ }^{131} \mathrm{I} \text { in discharges from the } \\
\text { holding tanks to sewer should remain below } 5 \mathrm{~Bq} / \mathrm{l} \text {. }\end{array}$ \\
\hline $\begin{array}{l}\text { The } \\
\text { Netherlands }\end{array}$ & & $\checkmark$ & $\begin{array}{l}\text { Radioactive waste with radionuclides with half- lives below } 100 \text { days should be stored for up to } 2 \\
\text { years to allow for decay. No specific mention is made or requirements for patient excreta. }\end{array}$ \\
\hline
\end{tabular}

Table 1: List of countries that stipulate the installation of a wastewater treatment plant for patient excreta [Punt 2010].

\begin{tabular}{|c|c|c|c|}
\hline \multirow{2}{*}{ Country } & \multicolumn{2}{|c|}{ Management approach } & \multirow{2}{*}{ Notes } \\
\hline & Direct discharge & Wastewater treatment & \\
\hline Denmark & $\checkmark$ & & $\begin{array}{l}\text { In Denmark there is no limit for the total activity that can be discharged (that is controlled by limits for } \\
\text { purchase and use.) However, dilution of }{ }^{131} \text { I discharges to } 0.1 \mathrm{MBq} / \mathrm{l} \text { required at the point where the hospital } \\
\text { drain meets the municipal sewer. }\end{array}$ \\
\hline Finland & $\checkmark$ & & $\begin{array}{l}\text { Discharge limits from institutions do not apply to patient excrete that may be freely discharged to sewer as } \\
\text { long as discharges at any one time do not exceed } 100 \mathrm{MBq} \text { and that over the course of a year does not } \\
\text { exceed } 100 \mathrm{GBq} \text {. }\end{array}$ \\
\hline Sweden & $\checkmark$ & & $\begin{array}{l}\text { Free release to sewer is the preferred option. Decision based on direct measurements at a large hospital. } \\
\text { External radiation exposure to sewer worker of } \sim 2 \mu \mathrm{Sv} \text { calculated on basis of } 50 \mathrm{GBq}^{131} \text { per year direct } \\
\text { release to sewer. }\end{array}$ \\
\hline
\end{tabular}

Table 2: List of countries that allow direct discharge of patient excreta after dilution [Punt 2010].

\begin{tabular}{|c|c|c|c|}
\hline \multirow{2}{*}{ Country } & \multicolumn{2}{|c|}{ Management approach } & \multirow{2}{*}{ Notes } \\
\hline & Direct discharge & Wastewater treatment & \\
\hline Greece & $\checkmark$ & $\checkmark$ & $\begin{array}{l}\text { Direct discharge to sewer allowed, provided that the wastewater is readily dispersible } \\
\text { in water and the maximum concentration of radioactive substances is not greater than } \\
3.7 \mathrm{MBq} / \mathrm{l} \text {. For }{ }^{131} \text { I thyroid post-operatory therapy wastewater decay storage prior to } \\
\text { discharge to sewer is required to meet this criterion. }\end{array}$ \\
\hline Republic of Ireland & $\checkmark$ & $\checkmark$ & $\begin{array}{l}\text { Both direct discharge to sewer and use of holding tanks are currently employed. } \\
\text { Hospitals are granted with authorisation on activity being administered. }\end{array}$ \\
\hline Spain & $\checkmark$ & $\checkmark$ & $\begin{array}{l}\text { Clearance levels are used to determine disposal routers. Where activities are above } \\
\text { clearance levels waste should be stored for decay. }\end{array}$ \\
\hline Great Britain & $\checkmark$ & $\checkmark$ & $\begin{array}{l}\text { Direct discharge to sewer allowed, but sites are required to demonstrate BPM and that } \\
\text { the critical group dose constraint of } 300 \mu \mathrm{Sv} / \mathrm{y} \text { is not exceeded. Consideration being } \\
\text { given to use of delay thanks for new facilities undertaking treatment of large numbers } \\
\text { of patients with }{ }^{131} \text {. }\end{array}$ \\
\hline
\end{tabular}

Table 3: List of countries that permit both approaches to patient excreta management [Punt 2010].

\section{Name}

University Clinic, Würzburg

Katharinen Hospital, Stuttgart

Helios Clinic, Wuppertal

Rhön Clinic, Hildesheim

Helios Clinic, Bad Saarow

University Clinic, Jena

Sisters of Charity Hospital, Linz

\begin{tabular}{|l|l|}
\hline No. of beds & Country \\
\hline 14 & Germany \\
\hline 12 & Germany \\
\hline 14 & Germany \\
\hline 10 & Germany \\
\hline 11 & Germany \\
\hline 10 & Germany \\
\hline 8 & Austria \\
\hline
\end{tabular}

Table 4: List of reference locations that are already using BioChroma technology.

is collected in the final storage tanks, where it is subject to constant monitoring, before being ultimately discharged into the sewage system.

\section{Advantages of the BioChroma system}

The advantages offered by the BioChroma system compared with processing systems that use the delay and decay principle are summarised in the following list:
- BioChroma is a patent-protected technology, which guarantees a competitive edge.

- Thanks to its high degree of technological innovation and lower requirement of reaction volumes, overall space requirements can be reduced by $50 \%$.

- The combination of the various process steps allows a more flexible operation. 
Citation: Rodríguez JC (2011) Biochroma - A New and Patented Technology for Processing Radioactive Wastewater from Nuclear Medicine Therapy Facilities in Hospitals and Clinics. J Nucl Med Radiat Ther 2:117. doi:10.4172/2155-9619.1000117

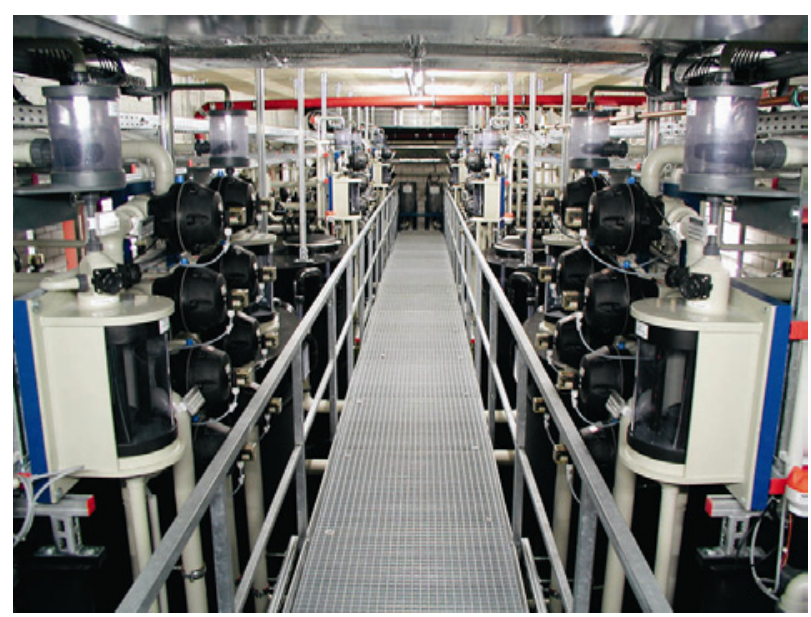

Picture 1: Example of a delay and decay system developed and built by EnviroDTS (Robert Bosch Hospital, Stuttgart).

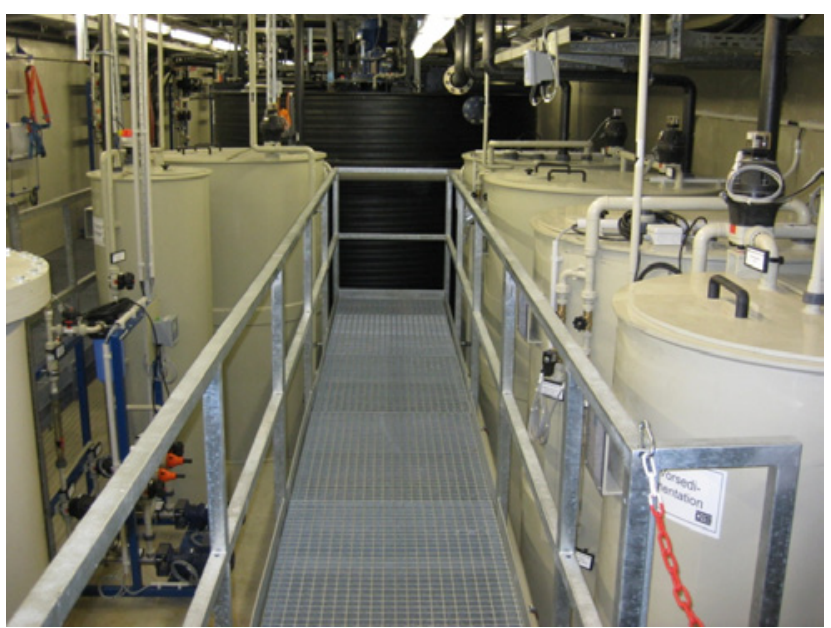

Picture 2: Bioreactors with sedimentation chambers (Katharinen Hospital, Stuttgart).

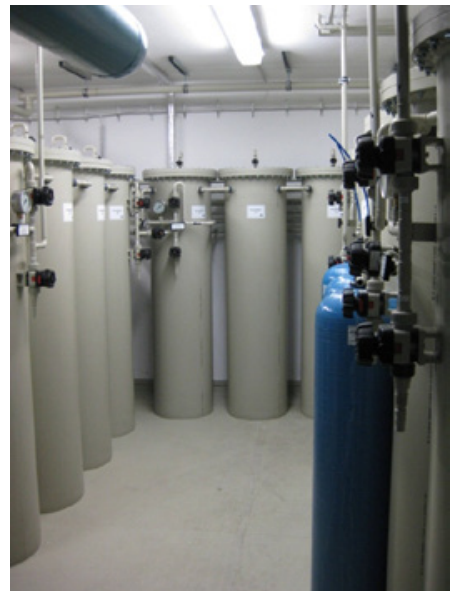

Picture 3: Overview of the adsorption filter modules with activated carbon (Katharinen Hospital, Stuttgart).
- BioChroma provides sufficient capacity to absorb sudden peaks, thus offering considerably enhanced comfort to final users (e.g. unlimited shower water operation).

- The nuclear medicine department can be easily extended (by up to $30 \%)$ on short notice.

- Unpleasant odours do not present any problems whatsoever throughout the entire system, due to the absence of anaerobic zones.

- A fully automated operation allows savings in personnel costs.

- Elimination of the risk of possible leakages or cross-contamination of the various radioactive effluents.

- Fewer safety measures have to be taken, since large holding tanks and their associated collecting basins (which are normally installed in systems that adopt the delay and decay principle) are not needed anymore.

- Thanks to their modular design, BioChroma systems are easy to install, irrespective of any on-site obstacles (e.g. cellars with a difficult access).

One additional and extremely significant advantage is the service life of about five years that can be achieved by active carbon filters and ion exchangers, which is much higher than that of other technologies. This high availability of the system is confirmed by experience gained with systems such as the one that has been installed at the Helios Clinic in Wuppertal, where the active carbon filters and ion exchange resins did not need to be replaced even after more than five years of operation.

EnviroChemie (through its subsidiary EnviroDTS) has a vast experience gained over more than 45 processing plants for radioactive wastewater in hospitals. Hitherto, the following hospitals have been equipped with BioChroma.

\section{Katharinen Hospital (Stuttgart) - project description}

A new nuclear medicine ward with 12 beds was planned for construction in the city of Stuttgart. Based on existing legislation, the responsible authorities and the company that operated the hospital agreed on a maximum activity level of $5 \mathrm{~Bq} / \mathrm{l}$ of the radionuclide ${ }^{131} \mathrm{I}$ in the final wastewater. If a typical delay and decay system would have been installed, the $180 \mathrm{~m}^{3}$ treatment plant that was already available in the hospital cellar would have to be extended by additional 150 $\mathrm{m}^{3}$. By implementing the patented BioChroma process, the space requirements were reduced to a minimum. For instance, since the new system was integrated into the existing installation, tanks accounting for $120 \mathrm{~m}^{3}$ could be used as buffering volume in the new wastewater treatment plant.

In the case of conventional delay and decay systems, water volume that can be processed each day is directly dependent on the total volume of the tanks and the ratio of initial activity to final activity of the radioisotope. The following formula can be used to calculate the number of patients:

$$
{ }^{\mathrm{n}} \text { pacient }=\lambda \frac{. \mathrm{V}_{\text {tank }} \cdot\left(\mathrm{n}_{\text {tank }}-1\right)}{\Delta \mathrm{V}_{\text {paciente }} \cdot\left(\operatorname{In} \mathrm{A}_{\text {initial }}-\operatorname{In} \mathrm{A}_{\text {final }}\right)}
$$

$\Delta \mathrm{V}_{\text {patient }}=$ volume of water/patient $/ \mathrm{d}$

$\lambda=$ decay constant $=\ln (2) / t_{112}$

$\mathrm{V}_{\text {tank }}=$ volume per tank

$\mathrm{n}_{\text {tank }}=$ number of tanks

$A=$ radioactive activity

Figure 2 shows some curves representing the largest number of patients that are possible for each technology depending on different volumes of daily water consumption per capita. In order to design the system to be installed at the Katharinen Hospital in Stuttgart, a 


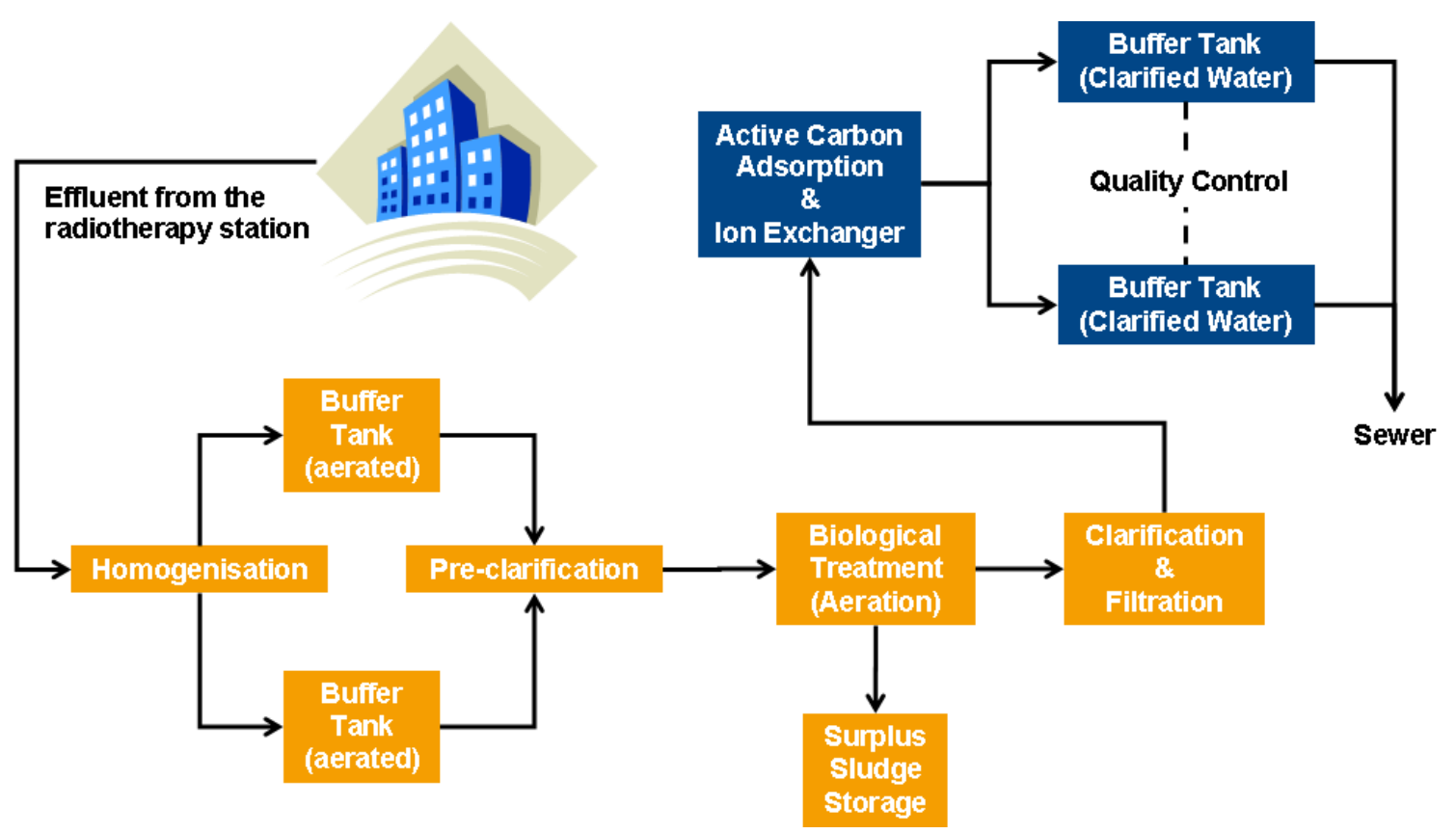

Figure 1: Flowchart describing the BioChroma process

$$
\mathrm{n}_{\text {pacient }}=\frac{\lambda \cdot \mathrm{V}_{\text {tank }} \cdot\left(\mathrm{n}_{\text {tank }}-1\right)}{\Delta \mathrm{V}_{\text {paciente }} \cdot\left(\ln \mathrm{A}_{\text {initial }}-\ln \mathrm{A}_{\text {final }}\right)}
$$

$\Delta \mathrm{V}_{\text {patient }}=$ volume of water/patient $/ \mathrm{d}$

$\lambda=$ decay constant $=\ln (2) / t_{1 / 2}$

$\mathrm{V}_{\text {tank }}=$ volume per tank

$\mathrm{n}_{\mathrm{tank}}=$ number of tanks

$A=$ radioactive activity

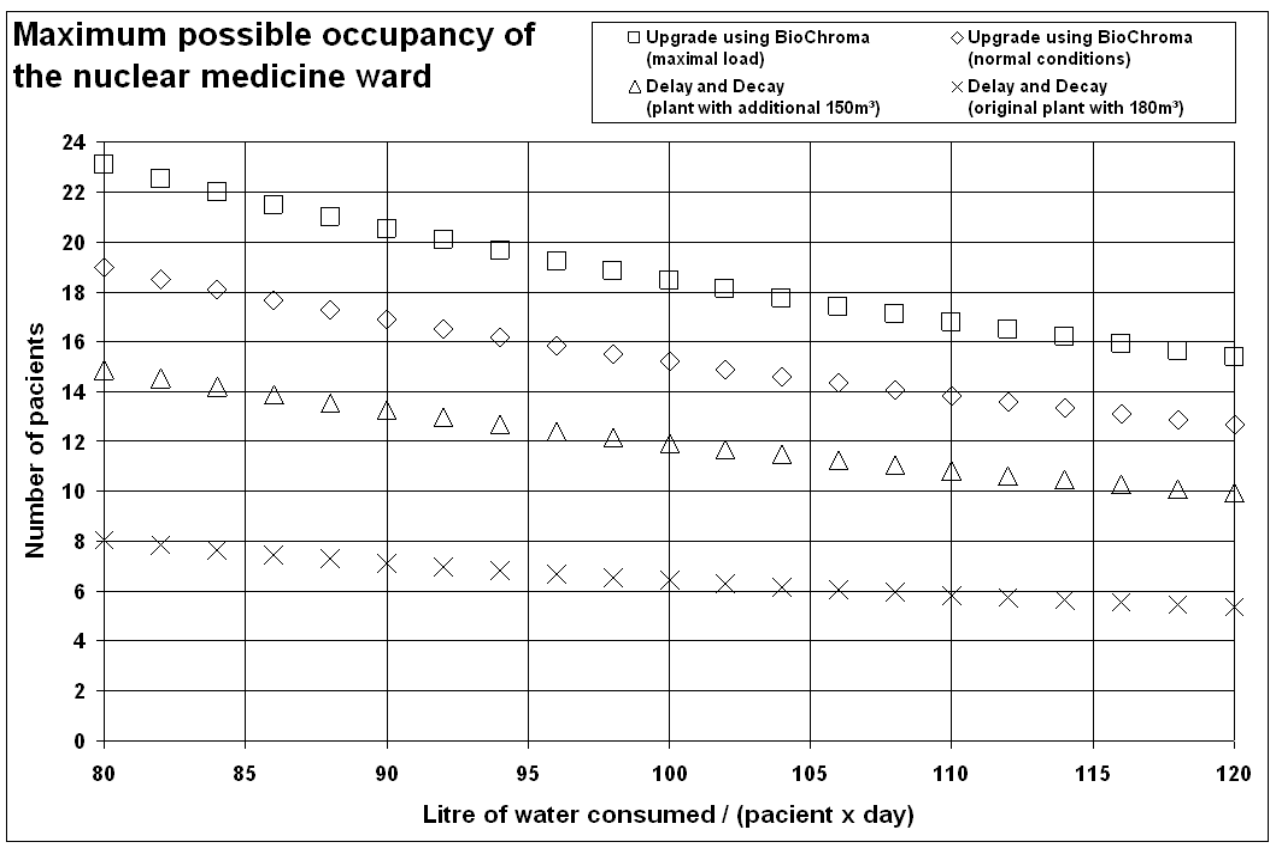

Figure 2: Maximum possible occupancy of the nuclear medicine department by technology and by daily wa-ter consumption per patient. 
daily consumption of 100 litres per patient was assumed, in order to guarantee a minimum comfort level. In comparison, the average daily consumption of 150 litres by a single-person-household in Europe can be used as a reference value for this figure. [Eurostat] The initial activity of the water was assumed to be $10^{6} \mathrm{~Bq} / \mathrm{l}$, whereas the target for final activity was $5 \mathrm{~Bq} / \mathrm{l}$. The result depicted in the curves shows the limited extent to which the existing system (equipped with a total volume of $180 \mathrm{~m}^{3}$ ) was working. Thus, the old installation was only able to afford 6 patients accommodated at the nuclear medicine ward.

In order to reach the targeted occupancy of 12 patients, additional $150 \mathrm{~m}^{3}$ of volume and $2500 \mathrm{~m}^{2}$ of space would have been necessary, if the Katharinen Hospital had decided to install an additional delay and decay treatment plant. Thanks to BioChroma, it was possible to integrate the new system into the existing plant and to use some of the already available tanks. Therefore, ultimately only $625 \mathrm{~m}^{2}$ more space was needed, which equated to a $75 \%$ reduction compared with the initial space requirement. Using BioChroma technology in this project enabled the nuclear medicine department to increase its capacity under normal operating conditions by $25 \%$ (i.e. 15 patients). Putting it differently, BioChroma allows the ward to accommodate the targeted number of 12 patients at a higher water use rate of 120 1/day instead of 100 l/day. Moreover, the BioChroma system can be "forced" to temporarily increase the processed water volume to the equivalent of that needed by 18 patients (i.e. $50 \%$ of the originally planned capacity).

The system installed in Stuttgart is equipped with homogenisation pumps that feed two buffer tanks. Bio-logical pre-treatment using pulsed oxygen administration takes place in these tanks. The radioactive waste-water is then pumped at a flow rate of 50 to $120 \mathrm{l} / \mathrm{h}$ to the biological treatment unit. Both the sedimentation of the solid matter and the aerobic treatment of the wastewater take place in this biological reactor. Thanks to continuous aeration, the micro-organisms in the activated sludge abate the organic load, while inorganic substances are oxidised to a certain extent. This process produces carbon dioxide and promotes the growth of the biomass (i.e. sludge) in the reactor. This biological treatment process also includes the nitrification of the organic nitrogen, i.e. ammonium is oxidised to nitrate.

The water emerging from the activated sludge reactor is pumped at a pressure of 0.4 and 0.9 bar through two biofilters and a sequence of 24 activated carbon filters, which are arranged in 6 modules containing 4 filters each. The average concentration at the inlet of the first module is $4,000 \mathrm{~Bq} / \mathrm{l}$ and is reduced by $90 \%$ to $400 \mathrm{~Bq} / \mathrm{l}$ at its outlet. The remaining modules gradually reduce the concentration of activity in the water until the final target of $5 \mathrm{~Bq} / 1$ is reached. One very important aspect of commissioning these modules is the use of water that has been inactivated under pressure (approximately 1 bar) to clean the filters in order to avoid problems of cross-contamination caused by residual air captured in the filters.

The water which has already been clarified is stored in final buffer tanks, where the quality is monitored prior to discharging the water into the sewage system. A water sample (one litre) is taken in order to measure the final radioactivity of the effluent. Any possible contamination of the sampling vessels or analysing equipment must be avoided if concentrations of less that $50 \mathrm{~Bq} / \mathrm{l}$ are to be measured. A calibrated, rectangular multi-purpose gamma camera without collimator is used for measuring purposes. The $3 / 8$ " sodium-iodine scintillation crystal can detect gamma radiation of $360 \mathrm{keV}$ with a probability of more than $50 \%$. It is importantn that sampling vessels have a lead shield at least $5 \mathrm{~cm}$ thick. Following this measurement protocol, even levels as low as $2 \mathrm{~Bq} / \mathrm{l}$ can be detected.

\section{Katharinen Hospital (Stuttgart) - Outcome of implementing the BioChroma system}

The system was successfully commissioned in the middle of 2008 . The operation of the plant is currently producing very good results with values below the specified limit of $5 \mathrm{~Bq} / \mathrm{l}$ for the isotope ${ }^{131} \mathrm{I}$. In addition, ${ }^{90} \mathrm{Y}$ has been reported to be eliminated at the same time.

Over the past two years of operation, the wastewater treatment plant has been able to achieve a maximum processing capacity of more than 2,000 l/day, which equates to a nuclear medicine ward with 20 beds. The highest level recorded during the test period (of 180 days after start-up) was a peak of nearly $2,800 \mathrm{l} /$ day. It is needless to say that these results have exceeded all expectations and underline the incredible potential offered by this new technology.

Summarising, it is fair to state that a BioChroma installation provides a nuclear medicine therapy facility with a higher level of operation flexibility. For example, a ward could be able to cope in the future with an extension of its capacity (number of patients) or to comply with stricter radiation regulatory limits without undertaking any expansion of the wastewater treatment plant.

\section{References}

1. Driver I, Packer S (2001) Radioactive waste discharge quantities for patients undergoing radioactive iodine therapy for thyroid carcinoma. Nucl Med Commun 22: 1129-1132.

2. Tavakoli M.B (2005) Radioactive discharge from patients with thyroid cancer under ${ }^{131}$ I treatment and its safe disposal to the public sewer system. Contemporary Oncology 9: 38-41

3. Rastogi RC, Linsley GS, Baekelandt LI (1998) Clearance of Materials Resulting from the Use of Radionuclides in Medicine, Industry and Research. IAEA TECDOC-1000. International Atomic Energy Agency, Vienna.

4. IAEA (2009) Release of Patients After Radionuclide Therapy IAEA Safety Report Series Number 63. International Atomic Energy Agency, Vienna.

5. Leung PM, Nikolic M (1998) Disposal of therapeutic ${ }^{131}$ I waste using a multiple holding tank system. Health Phys 75: 315-321.

6. Mitchell NG (2002) Agency Practice and Future Policy in Decay Storage of Radioactive Wastes. R\&D Technical Report P3-073/TR.

7. Punt A (2007) Radionuclide discharges to sewer - A field investigation. Science Report - SC020150/SR2, Environment Agency (UK)

8. Tuntawiroon M (2009) The Ninth Asia Oceania Congress of Medical Physics/ The Seventh South East Asia Congress of Medical Physics, 22-24 Octobe 2009.

9. Punt A (2010) Review of Best Practice in relation to lodine-131 Ablation Discharges to Sewer - Project Code RP005-0003, Radiological Protection Institute of Ireland.

10. IAEA (2005a) Management of Waste from the Use of Radioactive material in Medicine, Industry, Agriculture, Research and Education. IAEA Safety Guide WS-G-2.7 International Atomic Energy Agency, Vienna.

11. IAEA (2005b) Applying Radiation Safety Standards in Nuclear Medicine. IAEA Safety Report Series Number 40. International Atomic Energy Agency, Vienna.

12. ICRP (2007) Radiological protection and safety in medicine. Draft Recommendations 32/14/07, 12 January 2007.

13. Punt A (2010) Review of Best Practice in relation to lodine-131 Ablation Discharges to Sewer - Project Code RP005-0003, Radiological Protection Institute of Ireland.

14. BMJ, Bundesministerium der Justiz (2001) Verordnung über den Schutz vor Schäden durch ionisierendeStrahlen(StrlSchV)

15. DIN (2005a) DIN 6844-1:2005-01, Nuklearmedizinische Betriebe - Teil 1 Regeln für die Errichtung und Ausstattung von Betrieben zur diagnostischen Anwendung von offenen radioaktiven Stoffen.

16. DIN (2005b) DIN 6844-2:2005-01 Nuklearmedizinische Betriebe - Teil 2: Regeln für die Errichtung und Ausstattung von Betrieben zur therapeutischen Anwendung von offenen radioaktiven Stoffen. 
Citation: Rodríguez JC (2011) Biochroma - A New and Patented Technology for Processing Radioactive Wastewater from Nuclear Medicine Therapy Facilities in Hospitals and Clinics. J Nucl Med Radiat Ther 2:117. doi:10.4172/2155-9619.1000117

Page 6 of 6

17. EC (1999) Management of radioactive waste arising from medical establishments in the European Union. Proceedings of a Workshop, Brussels, 16-17 February 1999, EUR 19254.
18. IAEA (2000) Predisposal Management of Radioactive Waste, Including Decommissioning. IAEA Safety Requirement WS-R-2. International Atomic Energy Agency, Vienna. 